TITLE:

\title{
Assessment and Characteristics of DMSP Lyase Activity in Seawater and Phytoplankton Cultures
}

\section{$\operatorname{AUTHOR}(S)$ :}

HARADA, HYAKUBUN; HARADA, HYAKUBUN; KIENE, RONALD P.; KIENE, RONALD P.

\section{CITATION:}

HARADA, HYAKUBUN ... [et al]. Assessment and Characteristics of DMSP Lyase Activity in Seawater and Phytoplankton Cultures. Publications of the Seto Marine Biological Laboratory 2011, 41: 1-16

\section{ISSUE DATE:}

2011

URL:

http://hdl.handle.net/2433/159487

RIGHT: 
Publ. Seto Mar. Biol. Lab., 41: 1-16, 2011

\title{
Assessment and Characteristics of DMSP Lyase Activity in Seawater and Phytoplankton Cultures
}

\author{
Hyakubun HaRADA ${ }^{* 1,2}$ and Ronald P. KIENE ${ }^{1}$
}

\begin{abstract}
'Department of Marine Sciences, University of South Alabama, Mobile AL, 36688
and Dauphin Island Sea Lab, 101 Bienville Blvd, Dauphin Island, AL 36528. USA

${ }^{2}$ Seto Marine Biological Laboratory, Field Science Education and Research Center, Kyoto University, 459 Shirahama, Nishimuro, Wakayama, 649-2211. Japan

*corresponding author bharada@yahoo.com Tel: +81-(0)739-42-3515
\end{abstract}

\begin{abstract}
Dimethylsulfoniopropionate (DMSP) is produced by a wide variety of marine phytoplankton, and it can be enzymatically cleaved to dimethylsulfide (DMS) and acrylate by DMSP lyases. DMS formation in the sea plays an important role in the global sulfur cycle, yet the factors regulating production of DMS are poorly understood. We evaluated various procedures used for in vitro assays of DMSP lyase activity (DLA) of cells captured on filters. We also compared in vitro DLA from plankton material collected from diverse water samples, as well as from cultures of different phytoplankton species. The type of filter used to collect plankton material affected the apparent in vitro DLA, with glass fiber filters (Whatman GF/F) yielding higher rates than polycarbonate filters. Treatment of filtered plankton with Tris buffer $(200 \mathrm{mM}$ in $500 \mathrm{mM} \mathrm{NaCl}$ ), with vigorous mixing, appeared to permeablize cells allowing maximal DLA. We found that buffer $\mathrm{pH}$ and dithiothreitol (DTT) affected DLA positively or negatively depending on the phytoplankton species or water sample tested. In general, natural seawater plankton and cultured dinoflagellates had higher DLA with higher $\mathrm{pH}$ buffers ( $\mathrm{pH}$ range 6.5 - 8.5). In contrast, the prymnesiophytes Emiliania huxleyi and Phaeocystis antarctica had higher in vitro DLA at lower $\mathrm{pH}(\mathrm{pH}$ range $6.5-8.5)$, and DTT and Triton X-100 significantly increased the apparent enzyme activities. Not all phytoplankton contained detectable DLA, and DLA varied greatly among strains of the same species. DLA was however, detectable in all samples of particulate materials collected from a wide range of marine surface waters, including those from the coastal Gulf of Mexico, North Atlantic and Southern Ocean, and these samples showed patterns of high Chl a normalized DLA where high irradiances and low nutrients occur. Consistent with this observation, the phytoplankton cultures isolated from such environments also showed high DLA. Thus, light and nutrients may be important factors determining DLA. However, not all the variations in DLA were explained by light and nutrients, and these variations may be due to the different functions of DMSP lyases such as osmotic regulation, anti-grazing, and antioxidant activity.
\end{abstract}

Key words: DMSP lyase Activity, DLA, phytoplankton, Emiliania huxleyi, Phaeocystis antarctica

\section{Introduction}

Dimethylsulfide (DMS) plays an important role in the global sulfur cycle, accounting for $50 \%$ of biological sulfur input to the atmosphere (Bates et al., 1992). Emissions of DMS from the ocean result in the formation of sulfate aerosol particles which may affect global climate (Bates et al., 1987; Charlson et al., 1987). One pathway of DMS production is through the enzymatic cleavage of DMSP into DMS and acrylic acid by DMSP lyases. Many phytoplankton produce DMSP and both phytoplankton and bacteria produce the enzymes that cleave DMSP (Kiene 1990; Yoch et al., 1997; Stefels and VanBoekel, 1993). Studies of algal DMSP lyases have been relatively few, and these have used different methods to determine DMSP lyase activity (DLA). Additionally, only a few species of phytoplankton have been tested for DLA (Stefels et al., 1995; Stefels and Dijkhuizen, 1996; Steinke et 
al., 1998; Steinke et al., 2000; Yost and Mitchelmore, 2009).

The potential of phytoplankton cultures or natural plankton to convert Dimethylsulfoniopropionate (DMSP) into DMS has been measured either with in vivo (whole cell) assays (Stefels and VanBoekel, 1993; Scarratt et al., 2000) or with in vitro assays (Stefels and Dijkhuizen, 1996; Steinke et al., 2000). Addition of exogenous DMSPd to whole cell assays typically increases DMS production (Stefels and VanBoekel, 1993; Scarratt et al., 2000), however, in most cases it is unclear whether the dependence of DMS production rate on added DMSPd concentration in such assays reflects the capacity of plankton to transport DMSPd into cells and to the site of the lyases, or the capacity of extracellular lyases to cleave DMSP. DLA can also be measured at saturating levels of substrate DMSP after collecting cells on filters or preparing cell-free extracts (Stefels and Dijkhuizen, 1996; Steinke et al., 2000; Harada et al., 2004). In these cases, in vitro DLA was measured from the extracted or filtered plankton samples in a buffer.

Currently, there is no single protocol commonly used for in vitro DLA assays and it is unclear how factors such as cell harvesting methods, buffer $\mathrm{pH}$, substrate concentration, cell disruption, the presence of protease inhibitors or other factors affect the measured DLA. Lack of understanding in these areas makes it difficult to compare DLA measured in different studies. Unlike whole cell in vivo assays, in vitro DLA of permeablized cells represents the near maximum potential of the enzyme activity because all the enzymes are presumably free to react with the saturating level of the substrate. In fact, in vitro DLA was several orders of magnitude higher than the estimated in situ DMS release from the whole plankton community in the Atlantic Ocean (Harada et al., 2004), indicating that plankton apparently regulate the activity of cellular lyases to below their maximum potential in the natural environment.

The biological functions of DMSP lyase enzymes and the factors that affect them are still unclear. DMSP functions as an osmolyte and DMSP lyase may be used to control intracellular DMSP concentration. DMSP and its enzymatically cleaved products, DMS and acrylate, may be used as antioxidants (Sunda et al., 2002), or they may deter grazing (Wolfe et al., 1997; Strom et al., 2003). DMSP and DMS may also function as attractants to different members of the food web (Seymour et al., 2009; Steinke et al., 2009). DMSP could be produced as an overflow mechanism for excessive production of reduced compounds under unbalanced growth and DMSP lyases might be used to control over-accumulation of DMSP (Stefels, 2000). These functions are not necessarily mutually exclusive and phytoplankton may utilize DMS, DMSP and acrylate for multiple purposes. In natural seawater, DLA Chl $\mathrm{a}^{-1}$ was generally high near the surface and lower at depth (Steinke et al., 2002a; Steinke et al., 2002b; Harada et al., 2004). The DLA Chl a ${ }^{-1}$ ratio was also higher in water from the oligotrophic Sargasso Sea than in water from the more productive Gulf of Maine or North Carolina coast (Harada et al., 2004). Thus, DLA may be related to irradiance and nutrients. However, too few data exists on DLA from oceanic samples or phytoplankton cultures to reach any definitive conclusions as to the biological roles of DMSP lyases and the factors affecting DLA.

Planktonic production of DMS is very important for global geochemistry. Thus, understanding the characteristics of DMSP lyase for the accurate measurement of DLA would enable us to produce reliable and comparable data. Here we examined different methodological approaches for the measurement of in vitro DMSP lyase activity in natural plankton and cultured phytoplankton. Based on these tests, we chose a set of basic assay conditions and used the assay to determine the rates and characteristics of in vitro DLA in natural waters and phytoplankton cultures.

\section{Material and Methods}

Natural plankton and culture samples

Coastal seawater samples were collected at Dauphin Island and Gulf Shores, Alabama (30 $14^{\prime} 5^{\prime \prime}$ $\mathrm{N}, 88^{\circ} 7^{\prime} 33^{\prime \prime} \mathrm{W}$ and $30^{\circ} 13^{\prime} 4^{\prime \prime} \mathrm{N}, 87^{\circ} 59^{\prime} 5^{\prime}$ ' $\mathrm{W}$, respectively) and off a pier at the NOAA laboratory in Beaufort, North Carolina, USA ( $34^{\circ} 43^{\prime} 8^{\prime \prime}$ N, $\left.76^{\circ} 40^{\prime} 16^{\prime \prime} \mathrm{W}\right)$. Offshore water was collected for the 
filter material test in the Gulf of Maine on April 82002 ( $\left.43^{\circ} 03^{\prime} \mathrm{N}, 68^{\circ} 17^{\prime} \mathrm{W}\right)$. Oceanic surface water was collected in the Ross Sea on December 31, 2004, and January 17 and 19, 2005 (77 ${ }^{\circ} 0^{\prime} \mathrm{S}, 180^{\circ} 0^{\prime}$ E and $\left.74^{\circ} 3^{\prime} \mathrm{S}, 173^{\circ} 3^{\prime} \mathrm{E}\right)$. Oceanic water samples were collected for depth profile measurements from two contrasting sites: the oligotrophic Sargasso Sea near the Bermuda Atlantic Time-Series Study station in July-August 2004 (two eddies approximately at $30^{\circ} \mathrm{N}, 65^{\circ} \mathrm{W}$ and $29^{\circ} \mathrm{N}, 63^{\circ} \mathrm{W}$ ), and in the Southern Ocean, near the northern edge of seasonal sea ice south of New Zealand in November 2003 $\left(65^{\circ} 20^{\prime} \mathrm{S}, 177^{\circ} 04^{\prime} \mathrm{E}\right)$.

Media for phytoplankton cultures grown at the Dauphin Island Sea Lab were prepared from 0.2 $\mu \mathrm{m}$ filtered Gulf of Mexico or Sargasso Sea water. The salinity was adjusted to 30 ppt with $18 \mathrm{M} \Omega$ nanopure water and appropriate amounts of nutrients were added following the protocols of the Provasoli-Guillard National Center for Culture of Marine Phytoplankton (CCMP). Media were sterilized by autoclaving. The list of phytoplankton used in this study is given in Table 1. In addition, Phaeocystis globosa CCMP627 was also used. This species was not listed due to inconsistent DLA with respect to $\mathrm{pH}$ changes. It is possible that this strain may have two or more DMSP lyase enzymes and relative activities of these enzymes may change at different growth stages or environment. All cultures were grown under $60 \mu \mathrm{mol}$ photon $\mathrm{m}^{-2} \mathrm{~s}^{-1}$ fluorescent light with a $12 \mathrm{~h} / 12 \mathrm{~h}$ :dark/light cycle, unless otherwise specified.

General approach for DMSP lyase activity measurements

DLA was determined in plankton samples using an in vitro assay that measured the production rate of DMS under near saturating DMSP concentrations. The assay format that we used was based on that described by Steinke et al. (2000) with some modifications. For each sample assay, plankton from a known volume of seawater or culture was filtered onto a $25 \mathrm{~mm}$ diameter filter. The filter was subsequently placed in a $14 \mathrm{ml}$ serum vial with $1 \mathrm{ml}$ buffer. The vials with filter and buffer were sealed with a Teflon-coated gray butyl stopper (Wheaton), vortexed, and then incubated at $30^{\circ} \mathrm{C}$ in a water bath for 20 minutes. After this incubation, $\mathrm{DMSP} \cdot \mathrm{HCl}$ was added to the vial from a $250 \mathrm{mM}$ stock solution. DMSP lyases converted DMSP to DMS and presumably acrylate in the vial, and DMS diffused from the liquid to headspace of the vial. Immediately prior to sampling, the vial was vortexed vigorously for few seconds to equilibrate the headspace with the liquid phase, and a 100- $\mu 1$ headspace sample was subsequently removed with a Hamilton gas tight syringe and injected into a gas chromatograph for quantification of DMS. In addition, controls consisting of two vials containing buffer and DMSP were also prepared for each assay set to measure the abiological production of DMS. At least three headspace samples were measured for each vial to yield a rate of DMS increase with time; DMS production was linear over the time period of sampling. The DMSP lyase activities in plankton samples were corrected for abiotic cleavage of DMSP by subtraction of the DMS production rates measured in the control vials. For seawater samples the measured DLA was normalized either to the volume of water filtered or to $\mathrm{Chl}$ a determined on parallel samples. For phytoplankton cultures, DLA was normalized to Chl a or biovolume. Standard curves for DMS produced in lyase assays were prepared in $14 \mathrm{ml}$ serum vials by adding microliter volumes of DMSP $\cdot \mathrm{HCl}$ stock solutions and cleaving the DMSP with $1.2 \mathrm{ml}$ of $1 \mathrm{~N} \mathrm{NaOH}$. The liquid volume in standard vials was the same as that in assay vials, and the ionic strength of solution phases were also similar, so that headspace DMS concentrations were comparable between standards and assay samples.

\section{DMSP measurements}

Concentrations of particulate DMSP (DMSPp) were measured after alkaline hydrolysis to DMS. Briefly, a known volume of water sample or culture was filtered by gravity onto a $47 \mathrm{~mm} \mathrm{GF} / \mathrm{F}$ filter $\left(\right.$ Whatman $^{\circledR}$ ) for seawater or a $25 \mathrm{~mm} \mathrm{~A} / \mathrm{E}$ filter for phytoplankton cultures, which was immediately placed into a $14 \mathrm{ml}$ serum vial with a Teflon-coated gray butyl stopper. DMSPp was cleaved to DMS by adding $1 \mathrm{ml}$ of $5 \mathrm{~N} \mathrm{NaOH}$ to the vials. The vials were incubated in the dark at room temperature, 
normally $25^{\circ} \mathrm{C}$, for at least 12 hours to complete the reaction. Headspace sub-samples were injected into the gas chromatograph and compared with standards prepared with DMSP $\cdot \mathrm{HCl}$ stock solutions at room temperature.

Analytical setup

The concentration of DMS was measured using a Shimadzu GC-9A gas chromatograph equipped with a sulfur-selective flame photometric detector. The column ( $3 \mathrm{~mm}$ x $2 \mathrm{~m}$; Supelco Inc.) was made of Teflon and was filled with Chromosil 330. The carrier gas was Helium with a flow rate of $60 \mathrm{ml} \cdot$ $\min ^{-1}$. The oven temperature was $100^{\circ} \mathrm{C}$ and the detector temperature was $175^{\circ} \mathrm{C}$.

Cell count and chlorophyll a measurements

Cell volume and numbers were measured with a Coulter Multisizer 3 particle counter (Beckman Coulter) equipped with a $100 \mu \mathrm{m}$ aperture tube and $3 \% \mathrm{NaCl}$ as diluent. Chl a concentrations were measured fluorometrically according to Strickland and Parsons (1968). Briefly, a known volume of water was filtered through $\mathrm{GF} / \mathrm{F}$ filters for seawater or A/E filters for phytoplankton cultures and extracted in $90 \%$ acetone for $24 \mathrm{~h}$ at $-4^{\circ} \mathrm{C}$. Chl fluorescence was measured before and after acidification by $80 \mu 1$ of $1 \mathrm{~N} \mathrm{HCl}$ with a Turner Designs TD-700 with a daylight white lamp (P/N 10045) and chlorophyll optical kit (P/N 7000-961).

Experimental conditions

Amphidinium carterae and offshore water from the Gulf of Maine were used to test two different types of filters for DLA assays. We used $25 \mathrm{~mm}$ diameter Whatman GF/F filters (glass fiber, $0.7 \mu \mathrm{m}$ nominal pore size $)$ and Nuclepore polycarbonate filters, $(0.8 \mu \mathrm{m}$ pore size $)$ to collect plankton samples. These filters were added to vials with buffer to measure abiological production of DMS as a control, and the filters had no effect on the production of DMS.

We used $200 \mathrm{mM}$ Tris [hydroxymethyl] aminomethane buffer with $\mathrm{HCl}$ in $500 \mathrm{mM} \mathrm{NaCl}$ solution for $\mathrm{pH}$ 8.5, 8.0, and 7.5. For pH 6.5, MES (2-[N-Morpholino] ethanesulfonic acid) buffer in $500 \mathrm{mM}$ $\mathrm{NaCl}$ was used. The standard $\mathrm{pH}$ was set to $\mathrm{pH} 8.0$ to reflect a value close to that of seawater. Buffer $\mathrm{pH}$ was known to affect lyase activity, but maximum activity can occur at basic or acidic $\mathrm{pH}$ depending on the species (Stefels and Dijkhuizen, 1996; Steinke et al., 2000). We therefore tested pH dependence of DLA in several different phytoplankton cultures and natural water samples.

For an in vitro lyase assay, cells should be disrupted so that enzymes freely react with the substrate. Tris buffer with vigorous mixing may or may not be sufficient to disrupt the cells. We tested the effects of cell disruption by sonicating the samples (Heat System Inc. XL2005) for $2 \times 15$ seconds an ice bath. We also tested the effects of a surfactant $(0.1 \%$ Triton X-100), which may increase the permeability of cell membranes. The effects of the reducing agent, dithiothreitol (DTT), and the serine protease inhibitors phenylmethylsulfonylfluoride and benzamidine, were also tested at 1-2 $\mathrm{mM}, 0.1 \mathrm{mM}$ and $1 \mathrm{mM}$, respectively.

Basic assay conditions for natural water samples

For the measurement of natural water DLA, particulate material was filtered onto $25 \mathrm{~mm}$ diameter $\mathrm{GF} / \mathrm{F}$ filters $(0.7 \mu \mathrm{m}$ nominal retention), and $1 \mathrm{ml}$ of $200 \mathrm{mM}$ Tris buffer $(\mathrm{pH} 8.0)$ in $500 \mathrm{mM} \mathrm{NaCl}$ was used. The assay temperature was $30^{\circ} \mathrm{C}\left(0^{\circ} \mathrm{C}\right.$ for the Ross Sea samples and the culture of Phaeocystis antarctica). The substrate DMSP concentration was $2.5 \mathrm{mM}$, and no other chemicals were added to the vials. The standard assay conditions were also applied to phytoplankton culture DLA, unless otherwise specified. 


\section{Results and Discussion}

Filter type and material

When Amphidinium carterae or the Gulf of Maine water was filtered onto either GF/F or polycarbonate filters, the GF/F-filtered samples showed two-fold to four-fold higher DLA, respectively, compared with the polycarbonate-filtered samples (Fig. 1). It is possible that lower DLA results from increased cell breakage on the polycarbonate type filter (Kiene and Linn 1999). While some cell breakage or leakage can also occur with glass fiber filters (Kiene and Slezak, 2006), we have consistently found higher DLA with glass fiber filters. We therefore chose to use GF/F filters in our standard assay procedures. Another advantage of glass fiber filters is that $\mathrm{Chl}$ a and other phytoplankton pigments are normally filtered onto GF/F or other glass fiber filters. Thus, collecting DLA and pigment samples on the same type of filter minimizes the bias when normalizing one factor with the other.

\section{Substrate DMSP concentration}

Amphidinium carterae did not show a substantial difference in DLA among different concentrations of DMSP between $1 \mathrm{mM}$ and $10 \mathrm{mM}$ (Figs 2A, B). When $20 \mathrm{mM}$ of DMSP was added, DLA was reduced to $64 \%$ of the mean of the other three $(2.5,5.0$ and $10 \mathrm{mM}$ ) treatments (Fig. $2 \mathrm{~B})$. We repeated the experiment with only $2.5 \mathrm{mM}$ and $20 \mathrm{mM}$ substrate DMSP concentration and observed a similar result ( $23 \%$ reduction in $20 \mathrm{mM}$ samples, data not shown). Karenia brevis also showed lower DLA with 10 and $20 \mathrm{mM}$ DMSP in the assay mixture than with 2.5 and $5 \mathrm{mM}$ DMSP (Fig. 2B). When $20 \mathrm{mM} \mathrm{DMSP} \cdot \mathrm{HCl}$ was added, the buffer $\mathrm{pH}$ was reduced from 7.98 to 7.79 (Fig. 2B). Thus, it was likely that $20 \mathrm{mM}$ DMSP caused lower DLA because A. carterae and K. brevis had $\mathrm{pH}$ optima at higher $\mathrm{pH}$ (Fig. 3C). In theory, near saturating levels of substrate concentration should give linear and identical increases of the products with time following the Michaelis-Menten kinetics. Based on our results, $1 \mathrm{mM}$ DMSP was sufficient for the near-saturation of the lyase reaction in our $A$. carterae samples. Higher concentrations of DMSP can be added, but because the stock solution of DMSP was prepared with a hydrochloride salt (i.e. DMSP $\cdot \mathrm{HCl}$ ), the buffer may be overwhelmed by excessively high concentrations of the acidic substrate. Stock solutions of DMSP $\cdot \mathrm{HCl}$ can be neutralized with alkaline solutions before addition to the vials but this procedure hydrolyzes some of the DMSP to DMS at a relatively high rate.

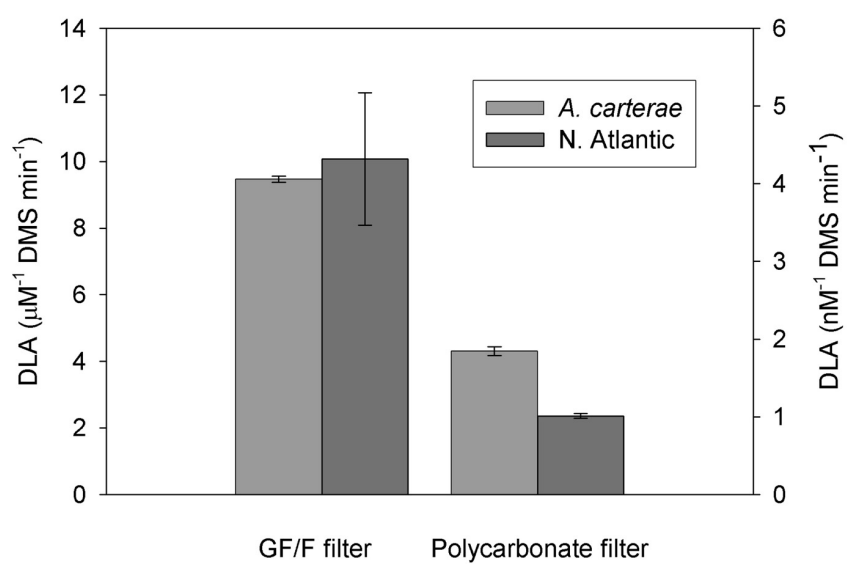

Fig. 1. Comparison between DLA obtained using either GF/F or track-etched polycarbonate filters to capture samples of the dinofalgellate Amphidinium carterae or natural water from the North Atlantic (Gulf of Maine). The assay was conducted at $\mathrm{pH} 8.0$ and $30^{\circ} \mathrm{C}$. 


\section{Effects of $\mathrm{pH}$}

For the $\mathrm{pH}$ tests, DLA was measured at the standard assay temperature of $30^{\circ} \mathrm{C}$ except for the samples from the Ross Sea and Phaeocystis antarctica, which were measured at $0{ }^{\circ} \mathrm{C}$. Other than the buffer and substrate, no other chemical additions were included in the standard assay. Estuarine water from Beaufort, North Carolina showed higher DLA at pH 7.5 and 8.0 than at pH 6.5 (Fig. 3A). Water samples from the Sargasso Sea, the Southern Ocean, and the Ross Sea also showed higher DLA with increasing pH from 6.5 to 8.5 (Fig. 3B). In addition, non-axenic A. carterae and axenic K. brevis showed higher DLA with increasing pH (Fig. 3C). In contrast, the prymnesiophytes, axenic Emiliania huxleyi CCMP373 and non-axenic P. antarctica, showed higher DLA at lower pH (Fig. 3D). This observation agrees with that of Steinke et al. (1998) who found that several E. huxleyi strains, including CCMP373, had pH optima between 5 and 7. However, axenic E. huxleyi CCMP 370 (Steinke et al., 1998) and a Phaeocystis sp. (Stefels et al., 1996) showed higher DLA with increasing $\mathrm{pH}$. Therefore, not all prymnesiophytes have enzymes with acidic $\mathrm{pH}$ optima. These observations suggest the presence of different DMSP lyase enzymes among different species of phytoplankton, which has been suggested before (Steinke et al., 1998).

Effects of cell disruption and chemical treatment

All assays were conducted at $30^{\circ} \mathrm{C}$ and $\mathrm{pH}$ 8.0. In addition, Emiliania huxleyi (CCMP373) was
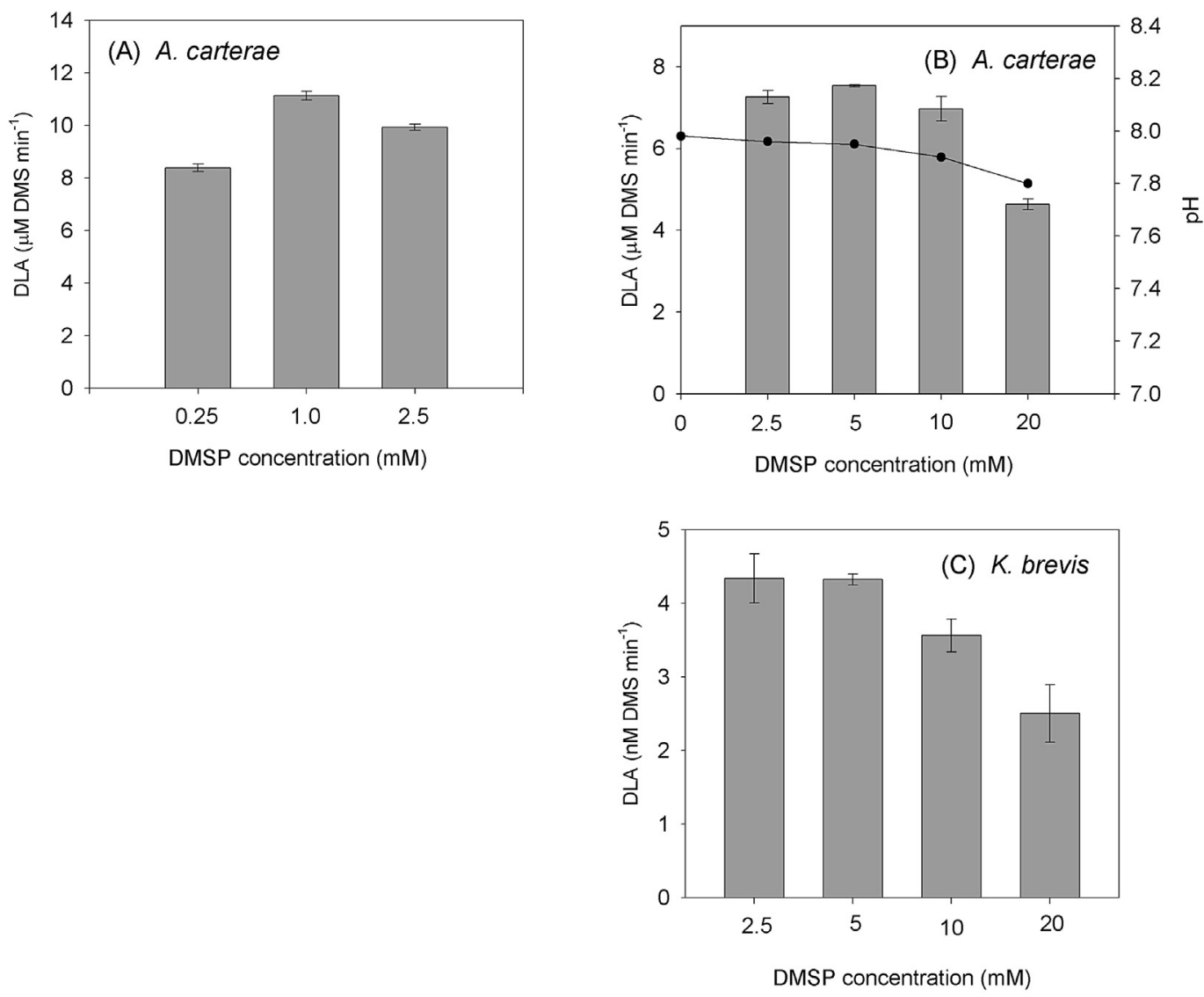

Fig. 2. DLA of Amphidinium carterae (A, B) and Karenia brevis (C) and buffer $\mathrm{pH}$ (line plot) at different DMSP concentrations in the assay mixture. 

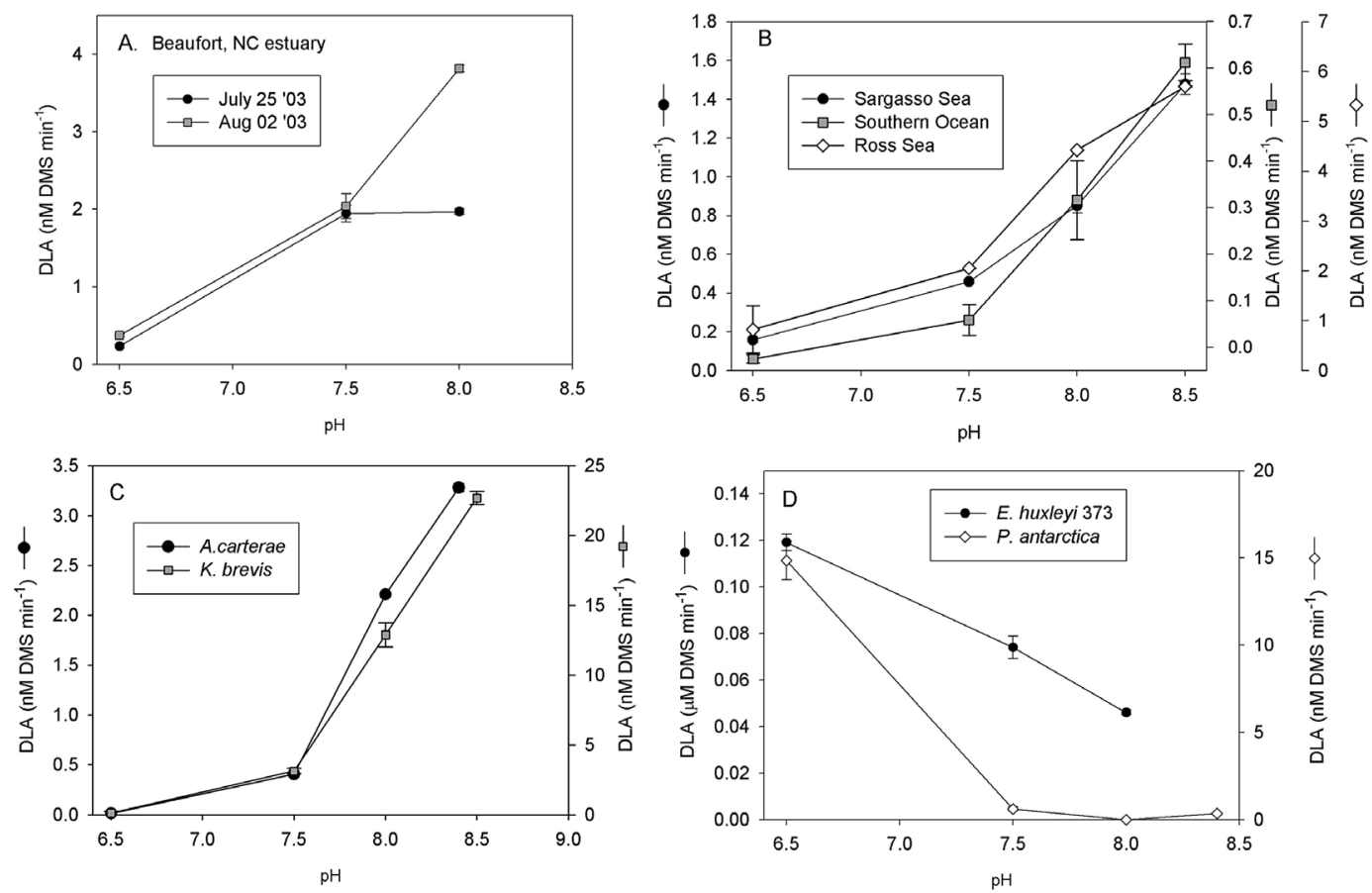

Fig. 3. DLA as a function of buffer $\mathrm{pH}$ for different water samples or phytoplankton cultures. (A) Samples from Beaufort, NC on July 25 and Aug 2, 2003, (B) sample from the Sargasso Sea, near Bermuda on July 15, 2004, the Southern Ocean on November 4, 2003 and the Ross Sea December 31, 2004, (C) dinoflagellates, non-axenic Amphidinium carterae and axenic Karenia brevis and (D) prymnesiophytes, axenic Emiliania huxleyi CCMP 373 and non-axenic Phaeocystis antarctica. Note that assay temperature was $0^{\circ} \mathrm{C}$ for the Ross Sea water and $P$. antarctica and $30^{\circ} \mathrm{C}$ for all other measurements.

also tested at $30^{\circ} \mathrm{C}$ and $\mathrm{pH}$ 6.5. Sonication showed no significant effects on DLA in two natural water samples and three prymnesiophyte cultures (Figs 4A, B). Only samples of Karenia brevis showed a significant effect of sonication (Fig. $4 \mathrm{C}$ ), and in this case the DLA was decreased by $28 \%(\mathrm{P}=$ 0.005). Sonication (membrane disruption) did not stimulate DLA with any of the samples, therefore Tris buffer with vigorous mixing appeared to be sufficient to permeablize cells and allow contact of the enzymes and substrate.

Dithiothreitol (DTT) is a reducing agent which protects sulfhydryl groups (Cleland 1963). Inclusion of $2 \mathrm{mM}$ DTT to the assay mixture caused a significant decrease of DLA in Amphidinium carterae $(-58 \%, \mathrm{P}=0.005)$ and $\mathrm{K}$. brevis $(-34 \%, \mathrm{P}=0.002)$ and a substantial, but non-significant, decrease in natural water samples from Gulf Shores $(-32 \%, \mathrm{P}=0.08$, Figs $4 \mathrm{~A}, \mathrm{C})$. On the other hand, $2 \mathrm{mM}$ DTT caused increases in apparent DLA with samples of coastal water from Dauphin Island, $P$. globosa, and E. huxleyi CCMP373 at $\mathrm{pH} 6.5$ (69, 71, and 51\% increase, $\mathrm{P}=0.069,0.019$, and 0.028, respectively, Figs 4A, B). The sampling sites at Gulf Shores and Dauphin Island are less than 10 miles apart and geographically similar environments on the Gulf of Mexico. However, the samples were taken eight months apart so it is likely that the species composition was different during each sampling. Stefels and Dijkhuizen (1996) observed a 5-fold increase of DLA in Pheocystis sp. (strain $\mathrm{K})$ with an addition of $1 \mathrm{mM}$ DTT. Thus, it is likely that DTT increases DLA in the prymnesiophytes, but not other species. 
Triton X-100 (0.1\%), which presumably solublizes cell membranes, had no effects on DLA from A. carterae, $K$ brevis and $P$. globosa but significantly increased DLA with E. huxleyi CCMP373 at both $\mathrm{pH} 8.0$ and 6.5 (both $\mathrm{P}<0.01$, Fig. 4). No test on the effects of Triton X-100 was conducted for the Gulf of Mexico waters. It appeared that Triton X-100 only affected acid-peak enzymes.

Effects of DTT, Triton X-100 and pH on DLA in samples from the Ross Sea and Phaeocystis antarctica

The DLA assays for P. antarctica and the Ross Sea water samples were carried out at $0{ }^{\circ} \mathrm{C}$ rather than $30^{\circ} \mathrm{C}$ to reflect ambient temperature of the polar waters. Tests showed that DLA assays at 0 and $30^{\circ} \mathrm{C}$ gave similar results in the ice-covered areas of the Southern Ocean (Harada, unpublished data). Thus, the DLA at these temperatures would have given comparable results. With non-axenic $P$. antarctica $111103 \mathrm{~A} 2$, DLA at $\mathrm{pH} 8.0$ was increased by 5.7 or 36 times by the inclusion of either DTT or Triton X-100, respectively, and adding a mixture of these chemicals resulted in 56 times higher DLA than in controls without the addition (Fig. 5A). P. antarctica showed an acidic DLA peak, and a mixture of DTT and Triton X-100 caused a large increase of DLA at pH between 6.5 and 8.5 (Fig. 5B). With natural water samples from the Ross Sea, the response of DLA to additions of DTT and Triton X-100 was different depending on the time and the location of sampling. On Dec. 31 2004, addition of DTT and Triton X-100 had no effect on DLA and the water sample taken on the same day had higher DLA in the alkaline buffer (Figs 6A, 3B). In contrast, samples collected on January 17 and 19, 2005 had low pH optima, and addition of DTT and Triton X-100 resulted in 12 times higher DLA
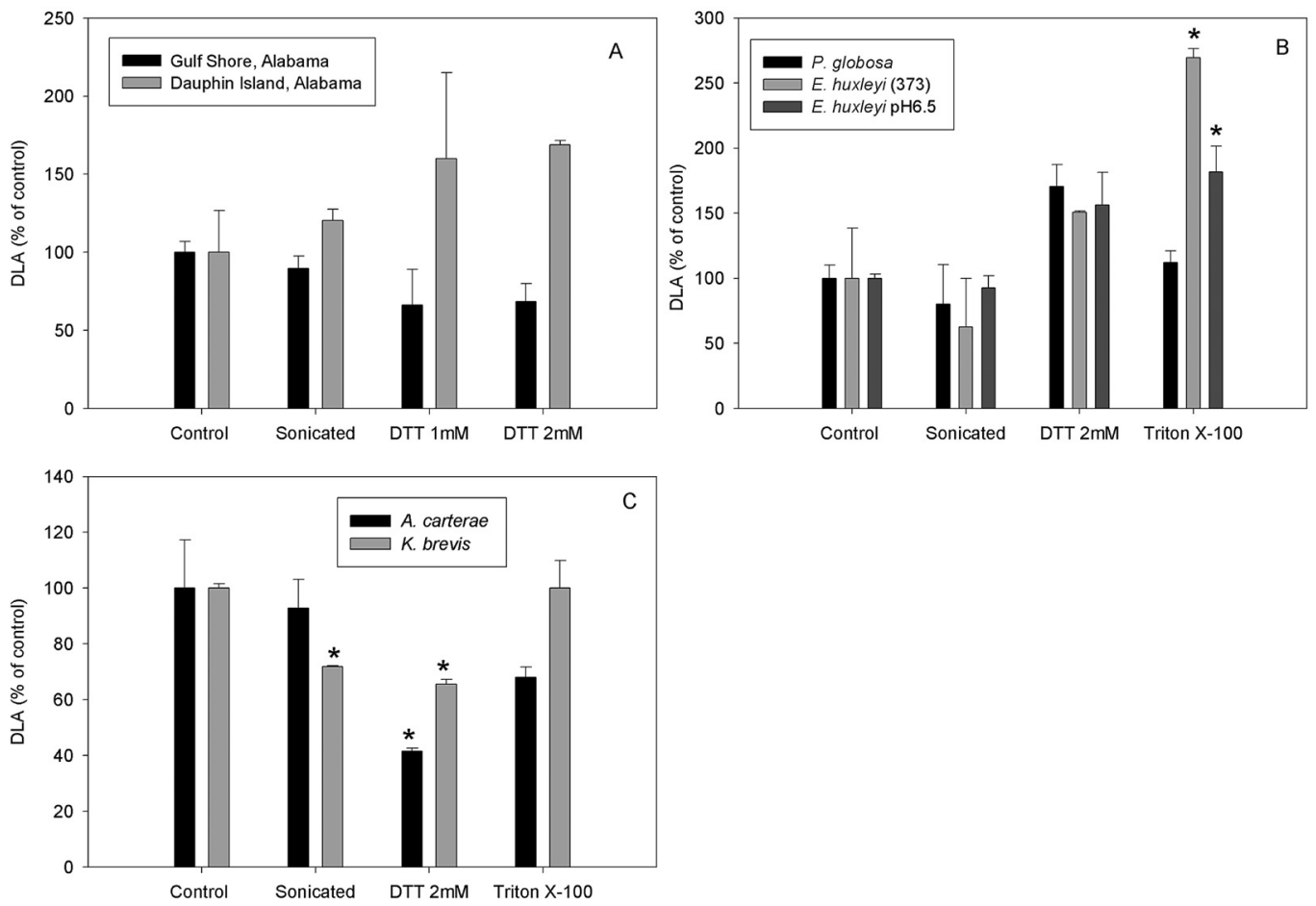

Fig. 4. Effects of sonication, DTT and Triton X-100 on apparent DLA in samples from (A) the northern Gulf of Mexico, (B) prymnesiophytes Phaeocystis globosa and Emiliania huxleyi CCMP 373 at pH 8.0 and 6.5, and (C) dinoflagellates, Amphidinium carterae and Karenia brevis at $30^{\circ} \mathrm{C}$ and $\mathrm{pH} 8.0$. In addition, Emiliania huxleyi CCMP 373 was also tested at $\mathrm{pH} 6.5$. The * indicates statistically significant difference between the treatment and control (t-test, $\alpha=0.01$ ). 

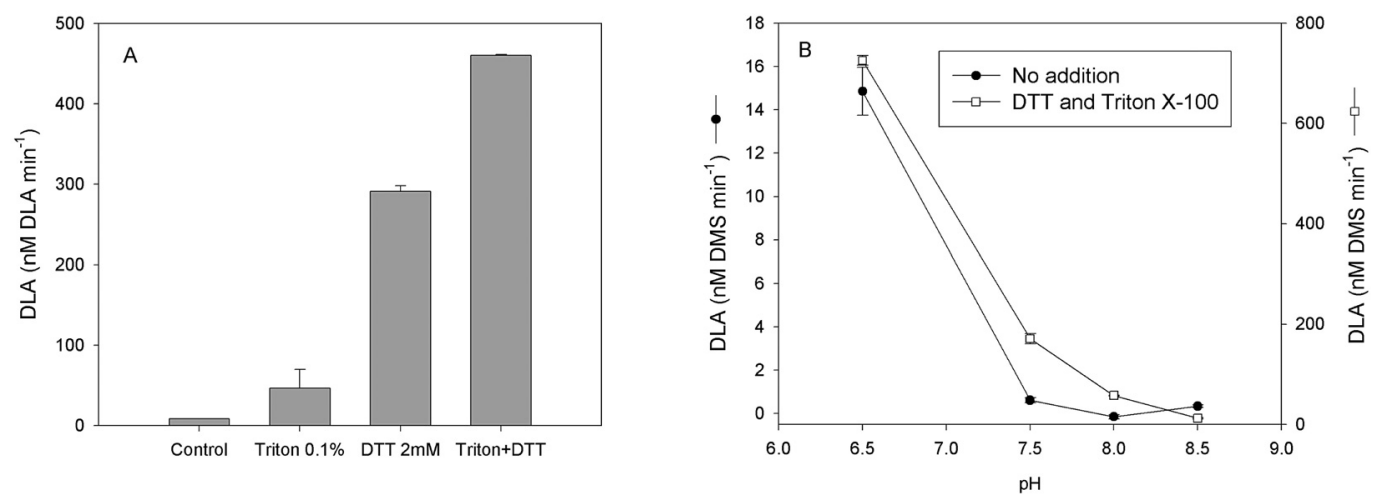

Fig. 5. Effects of $0.1 \%$ Triton X-100 and $2 \mathrm{mM}$ Dithiothreitol (DTT) on DLA from Phaeocystis antarctica at (A) $\mathrm{pH} 8.0$ and (B) in different $\mathrm{pH}$ buffers at $0^{\circ} \mathrm{C}$.
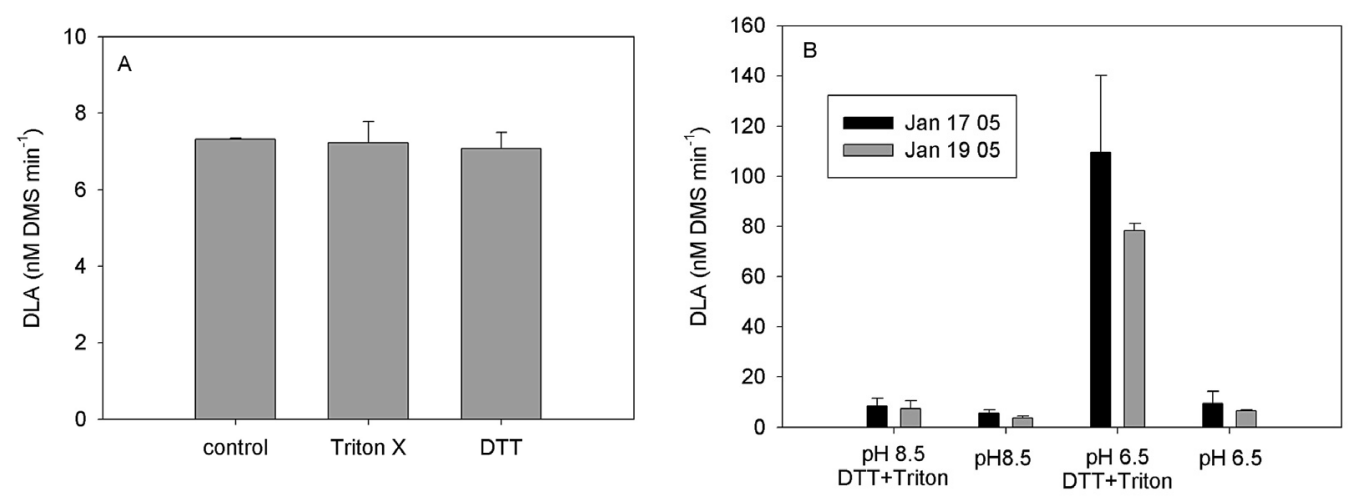

Fig. 6. Effects of $0.1 \%$ Triton $\mathrm{X}-100$ and $2 \mathrm{mM}$ DTT on apparent DLA $\left(\mathrm{pH} 8.0,0^{\circ} \mathrm{C}\right)$ in samples from the Ross Sea collected on Dec 31, 2004 (A). The sample taken on this day showed maximum DLA under alkaline conditions (Fig. 3). (B) Effects of 2mM DTT and $0.1 \%$ Triton X-100 on DLA at pH 8.5 and 6.5 on Jan 17 and 19,2005.

at $\mathrm{pH}$ 6.5, resembling the characteristics of P. antarctica DLA (Figs. 6B, 5). P. antarctica and diatoms were the most abundant phytoplankton during the sampling periods in the Ross Sea, and $P$. antarctica was presumably the high DMSP and DMSP lyase producer. The diatoms, Thalassiosira oceanica and T. pseudonana, and Skeletonema costatam had no detectable DLA at pH 8.0 and 6.5 (Table 1), and DLA by the dinoflagellates did not increase with the addition of Triton X-100 or DTT (Fig. 4B). In addition, Antarctic isolates of Mantoniella sp. and Pyramimonas sp. (prasinophytes) had no detectable DLA, and Polarella sp. (dinoflagellate) produced very low DLA compared to $P$. antarctica at $\mathrm{pH} 8.5$ and 6.5 (Harada, unpublished data). Thus, diatoms and other phytoplankton probably contributed little to DLA in the Ross Sea.

Comparison of DLA and intracellular DMSP concentrations among different species

Chl a-, cell number- and cell volume-normalized DLA along with intracellular DMSP concentrations were compared among different species (Table 1). DLA and DMSP were measured at 
or near the end of exponential growth. Emiliania huxleyi (CCMP374) had undetectable DLA from filtered samples, while E. huxleyi (CCMP373) showed very high DLA, $10.4 \mathrm{mM} \mathrm{min}^{-1}$, yet both strains of E. huxleyi had similar and high intracellular DMSP (approximately $300 \mathrm{mM}$ ). Steinke et al. (1998) detected DLA in CCMP 374 by centrifuging 1 liter of the culture and found that CCMP 373 had approximately 6000 times higher DLA than that of CCMP 374. CCMP 373 was isolated from the Sargasso Sea and CCMP 374 from the Gulf of Maine. The physiological difference between two $E$. huxleyi strains might have been a result of adaptations to different environments. The Sargasso Sea is oligotrophic with strong light exposure, while the Gulf of Maine is nutrient rich with relatively low light penetration into the water column. Harada et al. (2004) reported that Chl a normalized DLA was 20 times higher in the Sargasso Sea than in the Gulf of Maine, and Sunda et al. (2007) observed elevated DLA in a nitrate limited culture of CCMP 374. Therefore, light and nutrient availability may be very important factors for DLA.

Amphidinium carterae also showed a large variation of DLA between two strains. However, one strain was axenic (CCMP1314) and the other was not. The non-axenic strain had 4900 times higher Chl a normalized DLA than CCMP1314 (Table 1). Interestingly, CCMP1314 and the non-axenic A. carterae showed very high and similar intracellular DMSP concentrations, 326 and $288 \mathrm{mM}$, respectively. CCMP 1314 was isolated at an estuary in Falmouth, Massachusetts and the origin of non-axenic A. carterae was unknown. As we observed in E. huxleyi, A. carterae isolated from nutrient-rich water showed very low DLA. All three species of dinoflagellates tested (A. carterae, Lingulodinium polyedrum, and $K$. brevis) showed detectable DLA, but none of the diatoms or photosynthetic prokaryotes showed detectable DLA at pH 6.5 or 8.0 from filtrations of $50 \mathrm{ml}$ cultures (Table 1).

Table 1. General characteristics of DLA and DMSPp in different phytoplankton cultures. X indicates that DLA was below the detection limit and - indicates that no measurements were made. Note that a portion of DMSP, measured as DMS, in Lingulodinium polyedra may not be DMSP (gonyol may produce DMS in basic solution). All the assays were conducted at $30^{\circ} \mathrm{C}$, except Phaeocystis antarctica whose DLA was measured at $0{ }^{\circ} \mathrm{C}$. Assay $\mathrm{pH}$ was 6.5 in MES buffer for prymnesiophytes and 8.0 in Tris buffer for dinophytes. For Bacillariophytes and prokaryotes, both MES and Tris buffers were used at pH 6.5 and 8.0 , respectively, but no DLA was detected from $50 \mathrm{ml}$ filtration of the cultures.

\begin{tabular}{|c|c|c|c|c|c|c|c|c|}
\hline \multirow[t]{2}{*}{ Class } & \multirow{2}{*}{$\begin{array}{l}\text { Species } \\
\text { Strain }\end{array}$} & \multirow[t]{2}{*}{ Axenic } & \multirow{2}{*}{$\begin{array}{c}\text { DLA:Chl a } \\
\mathrm{mmol} \mathrm{min}^{-1} \mathrm{~g}^{-1}\end{array}$} & \multirow{2}{*}{$\begin{array}{l}\text { DLA:cell } \\
\text { fmol } \min ^{-1}\end{array}$} & \multirow{2}{*}{$\begin{array}{c}\text { DLA:cell vol } \\
\mathrm{mM} \mathrm{min}^{-1}\end{array}$} & \multirow{2}{*}{$\begin{array}{c}\text { DMSPp:Chl a } \\
\mathrm{mmol} \mathrm{g}^{-1}\end{array}$} & \multirow{2}{*}{$\begin{array}{c}\text { DMSPp:cell } \\
\text { Fmol }\end{array}$} & \multirow{2}{*}{$\frac{\text { DMSPp:cell vol }}{\mathrm{mM}}$} \\
\hline & & & & & & & & \\
\hline \multirow[t]{4}{*}{ Prymnisiophyceae } & Emiliania huxleyi & & & & & & & \\
\hline & CCMP373 & Yes & 1.24 & 0.254 & 7.94 & 47.6 & 9.7 & 304 \\
\hline & $\begin{array}{l}\text { Emiliania huxleyi } \\
\text { CCMP374 }\end{array}$ & Yes & $\mathrm{X}$ & $\mathrm{X}$ & $\mathrm{X}$ & 61.5 & 10.9 & 274 \\
\hline & $\begin{array}{l}\text { Phaeocystis antarctica } \\
111103 \mathrm{~A} 2\end{array}$ & No & 1.62 & $\mathrm{X}$ & $\mathrm{X}$ & - & - & - \\
\hline \multirow[t]{4}{*}{ Dinophyceae } & $\begin{array}{l}\text { Amphidinium cartrae } \\
\text { CCMP1314 }\end{array}$ & Yes & 0.0131 & 0.0246 & 0.0601 & 70.9 & 133 & 326 \\
\hline & $\begin{array}{l}\text { Amphidinium cartrae } \\
\text { non-axenic }\end{array}$ & No & 64.6 & 74.8 & 221 & 84.3 & 97.7 & 288 \\
\hline & $\begin{array}{l}\text { Lingulodinium polyedra } \\
\text { CCMP } 1738\end{array}$ & No & 0.077 & 1.71 & 0.192 & 5.4 & 119 & 13.3 \\
\hline & $\begin{array}{l}\text { Karenia brevies } \\
\text { CCMP } 2281\end{array}$ & Yes & 1.56 & 15.4 & 2.78 & 11.2 & 0.11 & 17.7 \\
\hline \multirow[t]{3}{*}{ Bacillariophyceae } & $\begin{array}{l}\text { Thalassiosira oceanica } \\
\text { CCMP1005 }\end{array}$ & Yes & $\mathrm{X}$ & $\mathrm{X}$ & $\mathrm{X}$ & - & - & - \\
\hline & $\begin{array}{l}\text { Thalassiosira pseudonana } \\
\text { CCMP1335 }\end{array}$ & Yes & $\mathrm{X}$ & $\mathrm{X}$ & $\mathrm{X}$ & - & - & - \\
\hline & $\begin{array}{l}\text { Skeltonema costatum } \\
\text { CCMP1332 }\end{array}$ & Yes & $X$ & $\mathrm{X}$ & $\mathrm{X}$ & - & - & - \\
\hline \multirow[t]{4}{*}{ Cyanophyceae } & $\begin{array}{l}\text { Synechococcus elongatus } \\
\text { CCMP } 1630\end{array}$ & Yes & $\mathrm{X}$ & $\mathrm{X}$ & $\mathrm{X}$ & - & - & - \\
\hline & $\begin{array}{l}\text { Synechococcus bacillaris } \\
\text { CCMP } 1333\end{array}$ & Yes & $\mathrm{X}$ & $\mathrm{X}$ & $\mathrm{X}$ & - & - & - \\
\hline & $\begin{array}{l}\text { Synechococcus sp. } \\
\text { CCMP1334 }\end{array}$ & Yes & $\mathrm{X}$ & $\mathrm{X}$ & $\mathrm{X}$ & - & - & - \\
\hline & $\begin{array}{l}\text { Prochlorococcus marinus } \\
\text { pastoris CCMP } 2389\end{array}$ & Yes & $\mathrm{X}$ & $\mathrm{X}$ & $\mathrm{X}$ & - & - & - \\
\hline
\end{tabular}




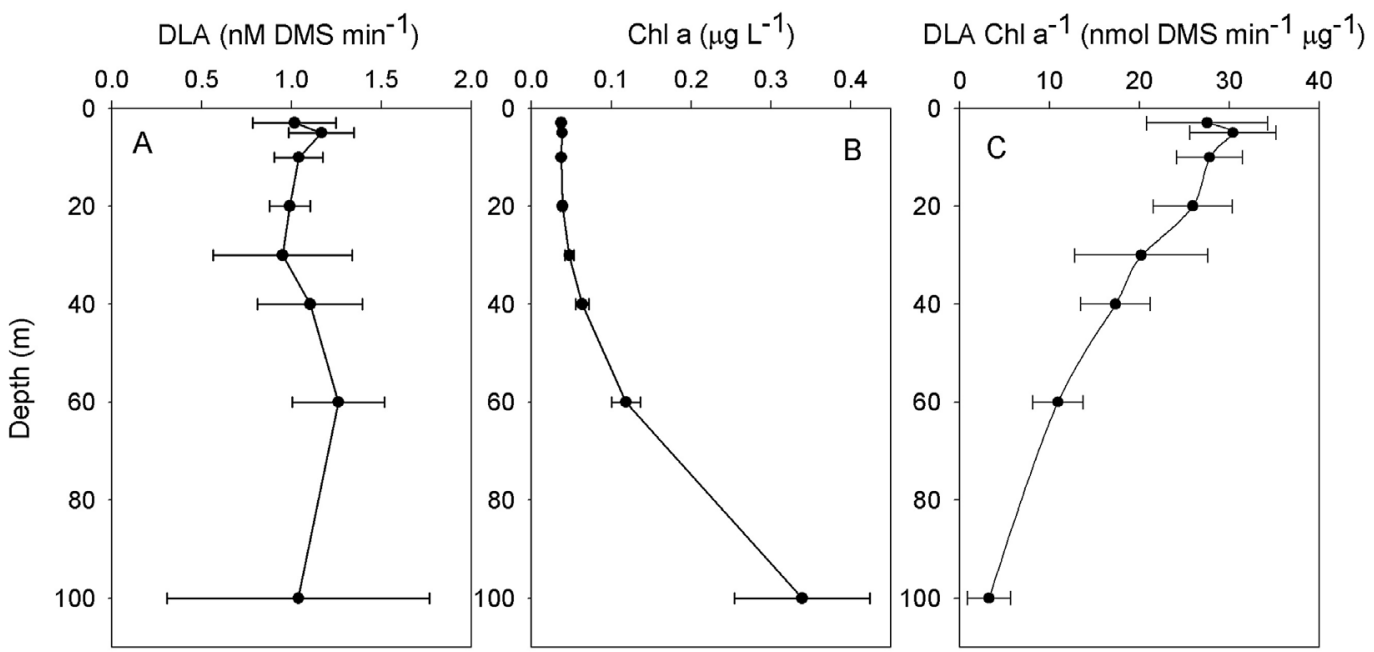

Sargasso Sea Eddy 1 (July 15-21, 2004)

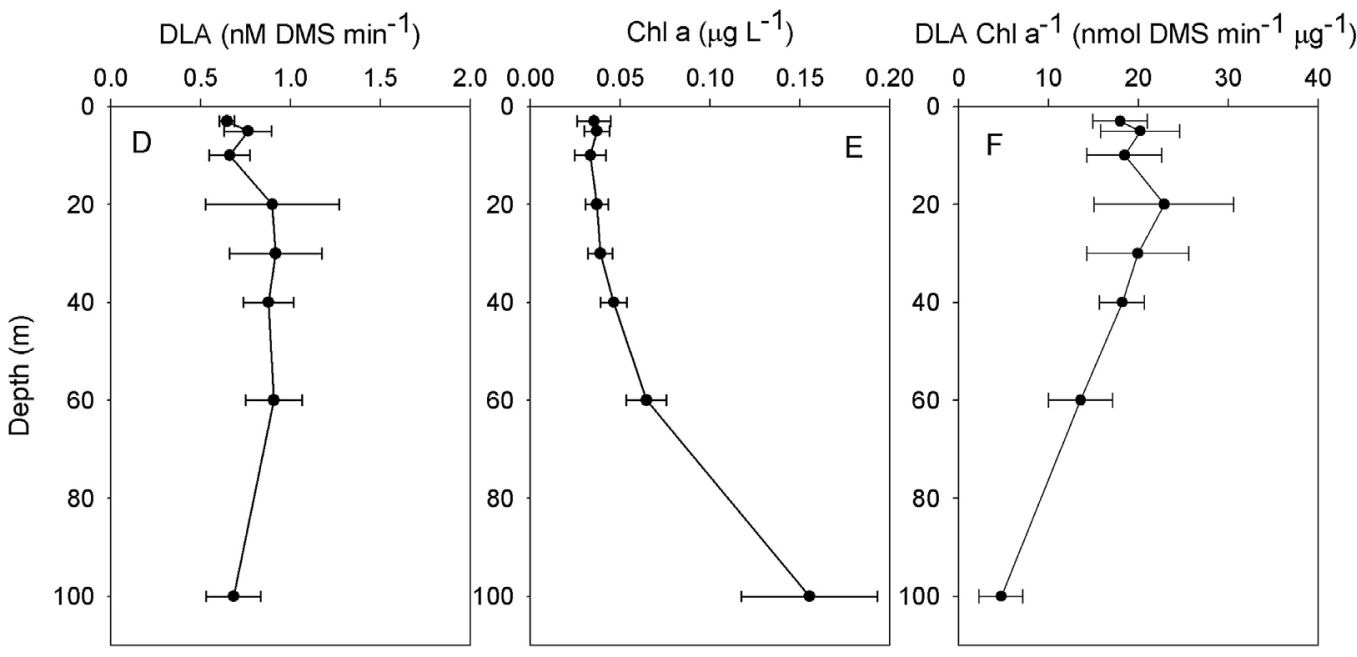

Sargasso Sea Eddy 2 (Jul 27-Aug 1, 2004)

Fig. 7. Vertical profiles of DLA (A and D), Chl a (B and E) and DLA Chl a ${ }^{-1}$ (C and F) from the Sargasso Sea, North Atlantic Ocean. Samples were taken every morning from two different eddies in the Sargasso Sea near Bermuda. Data in (A, B, and C) represent the mean profile obtained from daily profiles collected from July 15 to 21, 2004. Data in (D, E, and F) represents the mean profile from daily profiles collected from July 27 to August 1, 2004. Error bars represent a standard deviation of the means.

An additional experiment was conducted to test whether the bacteria in the culture contributed to the DLA in non-axenic A. carterae. Half a $\mathrm{ml}$ each of whole culture (bacteria + A. carterae), filtrate (A/E filter, $1.0 \mu \mathrm{m}$ nominal pore size; bacteria only) and autoclaved media (abiololgical control) were added to $1 \mathrm{ml}$ buffer and the DMS production rate measured. Bacteria $+A$. carterae, bacteria, and abiological control produced 3.86, 0.08 and $0.05 \mathrm{nM} \mathrm{DMS} \mathrm{min}^{-1}$, respectively, and the differences 

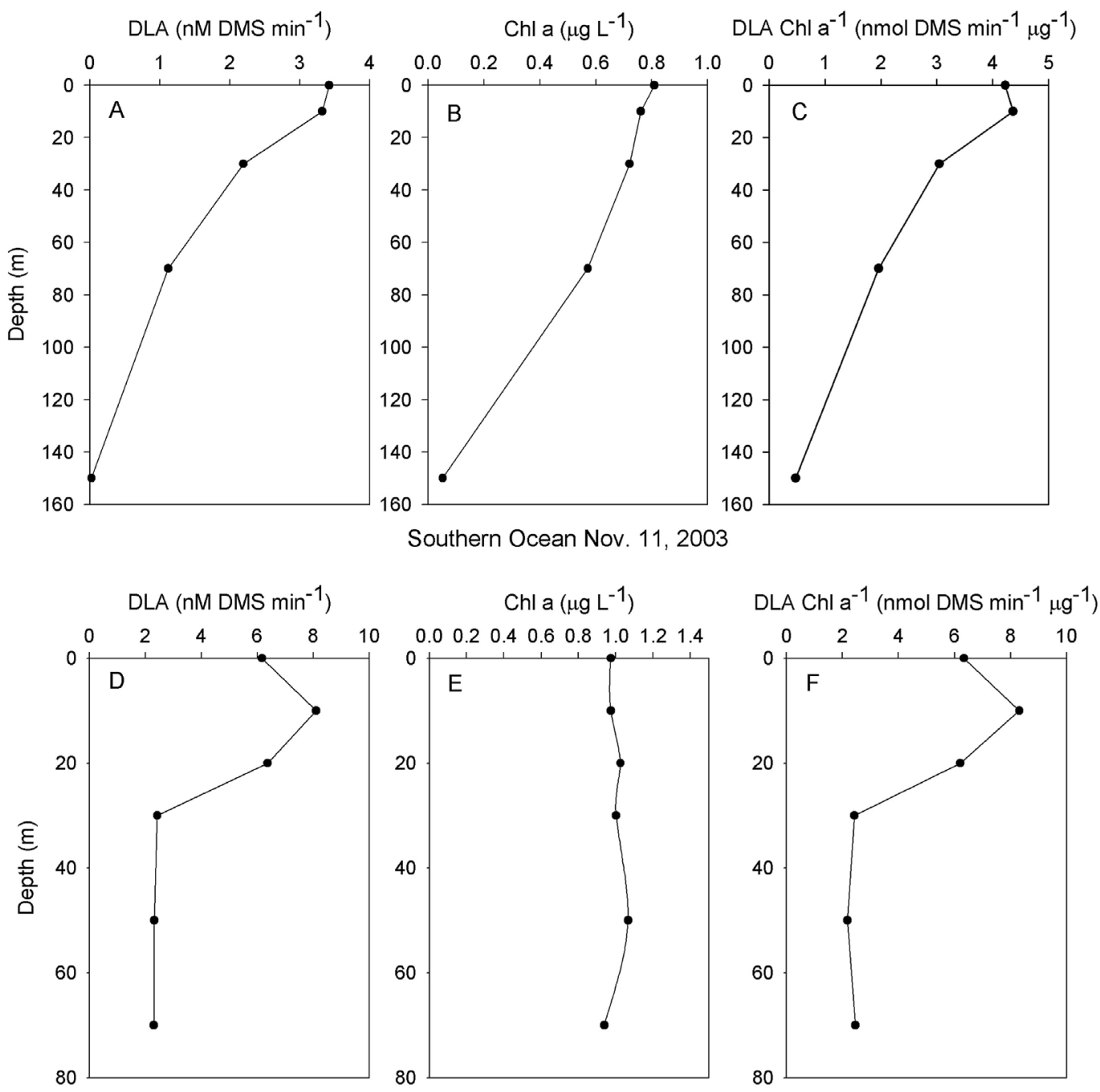

Southern Ocean Nov. 13, 2003

Fig. 8. Vertical profiles of DLA (A and D), Chl a (B and E) and DLA Chl a $\mathrm{a}^{-1}(\mathrm{C}$ and F) from the Southern Ocean south of New Zealand in November 2003. Data in (A, B, and C) represent the profile obtained on November 11, 2003, and data in (D, E, and F) represents the profile obtained on November 13, 2003.

were significant between bacteria $+A$. carterae and bacteria only treatments but not between bacteria and abiological control (one-way ANOVA with Holm-Sidak method, $\mathrm{P}<0.001$ and 0.11 , respectively). Only a small fraction of total bacteria are typically attached to phytoplankton (Smith et al., 1995), and it is unlikely that only the particle-attached bacteria have DMSP lyase. Therefore, DMS production from non-axenic A. carterae culture was mostly by A. carterae.

Depth profiles and Sea surface DLA from various locations

The basic assay conditions $\left(\mathrm{pH} 8.0,30^{\circ} \mathrm{C}\right.$; see the Materials and Methods section for details) were 
used for the measurements of DLA in several depth profiles from two environmentally distinct locations in the ocean. In the subtropical Sargasso Sea, the samples were taken from the surface to near the bottom of the euphotic zone from July 15 to 21, 2004 (first eddy) and from July 27 to August 1, 2004 (second eddy) (Fig. 7). In the Southern Ocean, north of the polar circle, samples were taken near the northern edge of seasonal sea ice where the photic zone was approximately $30 \mathrm{~m}$ deep (Fig. 8). Depth profiles of DLA and Chl a from the two locations did not show clear patterns. DLA was relatively constant in the Sargasso Sea, but high near the surface and decreased with depth in the Southern Ocean. Concentrations of $\mathrm{Chl}$ a were low near the surface and increased with depth in the Sargasso Sea. In contrast, Chl a concentrations at the Southern Ocean station decreased with depth on November 11 and were relatively uniform with depth two days later. Despite these differences in Chl a profiles, depth profiles of DLA Chl $\mathrm{a}^{-1}$ from the two locations revealed similar patterns, with both showing higher DLA Chl $\mathrm{a}^{-1}$ near the surface, and lower ratios at depth (Figs 7C, 7F, 8C, and 8F). These DLA Chl a ${ }^{-1}$ depth profiles were similar in shape to those in the Sargasso Sea in April 2002 (Harada et al., 2004), in the North Sea and North Atlantic (Steinke et al., 2002a; Steinke et al., 2002b) and in the northern ice edge of the Southern Ocean in December 2004 (Harada, 2007). It is important to note that the surface DLA Chl a ${ }^{-1}$ was five times higher in the Sargasso Sea than in the Southern

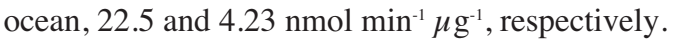

Rates of in vitro DLA from the present study and those reported in the literature are summarized in Table 2. The standard assay conditions were applied for the measurements of DLA, except that the assay temperature was $0^{\circ} \mathrm{C}$ in the Ross Sea and $30^{\circ} \mathrm{C}$ in the other locations. The highest mean DLA of $7.80 \mathrm{nM} \mathrm{min}^{-1}$ was observed in the Ross Sea 2004-2005 (Harada, 2007). These data were collected at several near-shore and offshore locations in the Ross Sea Polynya, where pennate diatoms and $P$. antarctica dominated the water. The highest mean DLA Chl a ${ }^{-1}$ was $43.8 \mathrm{nM} \mathrm{min}{ }^{-1} \mu \mathrm{g}^{-1}$ in the Sargasso Sea near the BATS station in April 2002 (Harada et al., 2004). Based on the pigment analyses, prymnesiophytes and prochlorophytes were abundant in the area, which also agrees with other studies (Haidar and Thierstein, 2001; Steinberg et al., 2001). The lowest DLA was $0.866 \mathrm{nM} \mathrm{min}{ }^{-1}$ at the Sargasso Sea site in July 2004. However, due to the very low Chl a concentration, DLA Chl a ${ }^{-1}$ was higher than other sampling areas except the Sargasso Sea in April 2002. Based on flow cytometry observations, Synechococcus spp. were the most abundant phytoplankton in the area in July, which agrees with the report by Steinberg et al. (2001). Although abundant, Synechococcus spp. and other phototrophic prokaryotes may not have contributed to particle-associated DLA in the Sargasso Sea because cultures of axenic Synecococcus sp. CCMP1334, S. elongatus CCMP1630, S. bacillaris CCMP1333, and Prochlorococcus marinus pastoris CCMP2389, did not have detectable amounts of DLA (Table 1). Additionally, the presence of dinoflagellates was likely very low in this area (Steinberg et al., 2001). This suggests that prymnesiophytes were likely the major DMSP lyase producers in these waters. The importance of the prymnesiophytes as major DMS producers was also

Table 2. Surface DMS, DMSPp, DLA and DLA Chl a ${ }^{-1}$ from various times and locations (numbers in parentheses are standard deviations). The assay temperature was $0^{\circ} \mathrm{C}$ in the Ross Sea to reflect ambient temperature and $30^{\circ} \mathrm{C}$ in the other locations.

\begin{tabular}{lcccc} 
& $\begin{array}{c}\text { DMS } \\
\mathrm{nM}\end{array}$ & $\begin{array}{c}\text { DMSPp } \\
\mathrm{nM}\end{array}$ & $\begin{array}{c}\text { DLA } \\
\mathrm{nM} \mathrm{min}\end{array}$ & $\begin{array}{c}\text { DLA:Chl a } \\
\mathrm{nM} \mathrm{min}\end{array} \mathrm{ug}^{-1}$ \\
\hline Ross Sea '04-05\# & $12.6(3.95)$ & $63.9(10.35)$ & $7.80(3.69)$ & $2.35(1.15)$ \\
\hline Southern Ocean Nov. 11 '03\# & 1.32 & 15.4 & 3.42 & 4.23 \\
\hline Gulf of Maine/Georges bank '02* & $1.17(1.01)$ & $32.4(8.2)$ & $2.61(1.94)$ & $2.15(2.24)$ \\
\hline Sargasso Sea '02* & $2.44(0.80)$ & $13.2(4.7)$ & $2.77(0.71)$ & $43.8(9.62)$ \\
\hline Sargasso Sea (BATS Station '04)\# & - & $7.73(0.897)$ & $0.866(0.24)$ & $22.5(6.71)$ \\
\hline North Carolina Coastal water 02* & 1.43 & 18.5 & 1.50 & 7.89 \\
\hline
\end{tabular}

\# Harada and Kiene (unpublished data) * Harada et al. (2004) 
suggested from other areas such as the Dutch coast and the Ross Sea (Stefels et al., 1995; DiTullio et al., 2003).

\section{Biological roles of DLA}

One possible role of DMSP lyase is to control intracellular DMSP concentration. DMSP is an osmolyte, but its concentration is not directly related to salinity, and phytoplankton do not quickly adjust DMSP to sudden salinity changes (Kirst, 1996; Van Bergeijk et al., 2003). In addition, since salinity is relatively constant in offshore waters, it seems unlikely that DMSP lyase enzymes are used for osmotic adjustment alone.

DMSP and its enzymatically cleaved products, DMS and acrylate, may be used as antioxidants (Sunda et al., 2002) or an overflow mechanism under imbalanced growth (Stefels, 2000). The observations of natural water samples obtained from various locations showed patterns of high Chl a normalized DLA where high irradiances and low nutrients occur, and DMS appeared to be high in such environment as well (Dacey et al., 1998; Simó and Pedrós-Alió, 1999). Consistent with this observation, the phytoplankton cultures isolated from such environments showed high DLA. High irradiance and low nutrients cause oxidative stress. Thus, our results support the role of DLA as a part of the DMSP antioxidant system. In addition, a low DLA strain of E. huxleyi CCMP374 increased DLA and the diatom, Thalassiosira oceanica, increased intracellular DMSP when cultures were nitrate limited (Sunda et al., 2007; Harada et al., 2009), thus, DMSP and its enzymatically cleaved products may serve as nitrogen-free antioxidants in oligotrophic environments. Alternatively, DMSP may be produced as a result of excessive carbon fixation relative to $\mathrm{N}$ assimilation under high irradiation or $\mathrm{N}$ limitation, and DMSP lyases prevent over accumulation of DMSP (Stefels, 2000). In this scenario, the role of DMSP lyase can be viewed as osmotic regulation in the overflow hypothesis. Although light and nutrient availability may be very important, there may be other factors affecting DLA as well. Steinke et al. (1998) reported that E. huxleyi CCMP 379 had nearly as high lyase activity as CCMP 373, yet this species was isolated in the English Channel where nutrients are relatively high and light penetration low. It is possible that certain phytoplankton maintain a high level of DLA in order to produce acrylate and DMS rapidly to deter grazing or to signal other organisms (Wolfe et al., 1997; Steinke et al., 2002c; Seymour et al., 2009). In addition, DMSP itself can deter grazing without the need for cleavage to the potentially toxic acrylic acid (Strom et al., 2003). These possible functions of DMSP lyases, such as osmotic regulation, antioxidant activity, and grazing deterrents, are not necessarily mutually exclusive and phytoplankton may utilize DMSP, DMS, and acrylate for multiple purposes.

DMS is very important in the global sulfur cycle, and planktonic DLA may be a significant factor affecting biological production of DMS. Up until now, however, few data existed on DLA in oceanic plankton and phytoplankton cultures. Ours is among the first studies to analyze, in detail, the characteristics of DLA from several geographically and environmentally different locations and from different classes of phytoplankton cultures. We found that the difference in the assay methods affected DLA greatly, such as filter materials, pH, DTT, and Triton X-100, and that irradiance, nutrient availability, and phytoplankton species composition may be very important factors affecting natural water DLA.

\section{Acknowledgements}

Support for this research was obtained from grants OPP 0230497 and OCE-02-21122 to R. P. Kiene and OPP 0221748 to P. Matrai. Our colleague Dave Kieber provided numerous helpful discussions related to this work. We thank Giacomo DiTullio for providing us with Chl a data from the Sargasso Sea and Julie Rose for providing us with P. antarctica aboard the Nathaniel B. Palmer. We also thank the captain, crew and scientists on board R/V Nathaniel B. Palmer and R/V Seward Johnson. 


\section{References}

Bates, T. S., Charlson, R. J., Gammon R. H. 1987. Evidence for the climatic role of marine biogenic sulphur. Nature, 329: 319-321.

Bates, T. S., Lamb, B. K., Guenther, A., Dignon, J., Stoiber, R. E. 1992. Sulfur emissions to the atmosphere from natural sources. J. Atmos. Chem., 14: 315-337.

Charlson, R., Lovelock, J. E., Andreae, M. O., Warren, S. G. 1987. Oceanic phytoplankton, atmospheric sulphur, cloud albedo and climate. Nature, 326: 655-661.

Cleland, W. W. 1963. Dithiothreitol, a new protective reagent for SH groups. Biochemistry, 3: 480-482.

Dacey, J. W. H., Howse, F. A., Michaels, A. F., Wakeham, S. G. 1998. Temporal variability of dimethylsulfide and dimethylsulfoniopropionate in the Sargasso Sea. Deep-Sea Res., 45: 2085-2104.

DiTullio, G., Jones, D., Geesey, M. 2003. Dimethysulfide dynamics in the Ross Sea during austral summer. Biogeochemistry of the Ross Sea Antarctic research series, 78: 279-294.

Haidar, A., Thierstein, H. 2001. Coccolithophore dynamics off Bermuda (N. Atlantic). Deep-Sea Res. (II Top. Stud. Oceanogr.), 48: 1925-1956.

Harada, H. 2007. Physiological roles of DMSP, DMSP lyase, DMS and DMSO in phytoplankton. Ph.D. Dissertation. University of South Alabama. Mobile. 146 pp.

Harada, H., Vila-Costa, M., Cebrian, M., Kiene, R. 2009. Effects of UV radiation and nitrate limitation on the production of biogenic sulfur components by marine phytoplankton. Aquatic Botany, 90: 37-42.

Harada, H., Rouse, M-A., Sunda, W., Kiene, R. 2004. Latitudinal and vertical distributions of particle-associated dimethylsulfoniopropionate (DMSP) lyase activity in the western North Atlantic Ocean. Can. J. Fish. Aquat. Sci., 61: 700-711.

Karsten, U., Wienke, C., Kirst, G. 1991. Growth pattern and $\beta$-dimethylsulphoniopropionate (DMSP) content of green macroalgae at different irradiances. Mar. Biol., 108: 151-155.

Keller, M. D., Korjeff-Bellows, W. 1996. Physiological aspects of the production of dimethylsulfoniopropionate (DMSP) by marine phytoplankton. In: Kiene R. P, Visscher P. T, Keller M. D., Kirst G. O. (eds) Biological and environmental chemistry of DMSP and related sulfonium compounds. Plenum, New York, pp 131-142.

Kiene, R. P. 1990. Dimethyl sulfide production from dimethylsulfoniopropionate in coastal seawater samples and bacterial cultures. Appl. Environ. Microbiol., 56: 3292-3297.

Kiene, R. P., Linn, L. J. 1999. Filter type and sampling handling affect determination of organic substrate uptake by bacterioplankton. Aquat. Microb. Ecol., 17: 311-321.

Kirst, G. O. 1996. Osmotic adjustment in phytoplankton and macroalgae: the use of dimethylsulfoniopropionate (DMSP). In: Kiene R. P., Visscher P. T., Keller M. D., Kirst G. O. (eds) Biological and environmental chemistry of DMSP and related sulfonium compounds. Plenum, New York, pp 121-129.

Scarratt, M., Cantin G., Levasseur, M., Michaud, S. 2000. Particle size-fractionated kinetics of DMS production: where does DMSP cleavage occur at the microscale? J. Sea Res., 43: 245-252.

Seymour, J. R., Simo, R., Ahmed, T. and Stocker, R., 2010. Chemoattraction to dimethylsulfoniopropionate throughout the marine microbial food web. Science, 329(5989): 342-5.

Simó, R., Pedrós-Alió, C. 1999. Role of vertical mixing in controlling the oceanic production of dimethyl sulphide. Nature, 402: 396-399.

Smith, D., Steward, G., Long R., Azam, F. 1995. Bacterial mediation of carbon fluxes during a diatom bloom in a mesocosm. Deep Sea Research (Part II, Topical Studies in Oceanography), 42: 75-97.

Stefels, J. 2000. Physiological aspects of the production and conversion of DMSP in marine algae and higher plants. J. Sea Res., 43: 183-197.

Stefels, J., Dijkhuizen, L. 1996. Characteristics of DMSP-lyase in Phaeocystis sp. (Prymnesiophyceae). Mar. Ecol. Prog. Ser., 131: 307-313.

Stefels, J., Dijkhuizen, L., Gieskes, W. W. C. 1995. DMSP-lyase activity in a spring phytoplankton bloom off the Dutch coast, related to Phaeocystis sp. abundance. Mar. Ecol. Prog. Ser., 123: 235-243.

Stefels, J., Gieskes, W., Dijkhuizen, L. 1996. Intriguing functionality of the production and conversion of DMSP in Phaeocystis sp. In: Kiene R. P., Visscher P. T., Keller M. D., Kirst G. O. (eds) Biological and environmental chemistry of DMSP and related sulfonium compounds. Plenum, New York, pp 305-335.

Stefels, J., van Leeuwe, M. A. 1998. Effects of iron and light stress on the biochemical composition of Antarctic Phaeocystis sp (Prymnesiophyceae). I. Intracellular DMSP concentrations. J. Phycol., 34: 486-495. 
Stefels, J., VanBoekel, W. H. M. 1993. Production of DMS from dissolved DMSP in axenic cultures of the marine phytoplankton species Phaeocystis sp. Mar. Ecol. Prog. Ser., 97: 11-18.

Steinberg, D. K., Carlson, C. A., Bates, N. R., Johnson, R. J., Michaels, A. F., Knap, A. H. 2001. Overview of the US JGOFS Bermuda Atlantic Time-series Study (BATS): a decade-scale look at ocean biology and biogeochemistry. Deep-Sea Res. II, 48: 1405-1447.

Steinke, M., Malin, G., Archer, S. D., Burkill, P. H., Liss P. S. 2002a. DMS production in a coccolithophorid bloom: evidence for the importance of dinoflagellate DMSP lyase. Aquat. Microb. Ecol., 26: 259-270.

Steinke, M., Malin, G., Gibb, S. W., Burkill, P. H. 2002b. Vertical and temporal variability of DMSP lyase activity in a coccolithophorid bloom in the northern North Sea. Deep-Sea Res. II, 49: 3001-3016.

Steinke, M., Malin, G., Liss, P. S. 2002c. Trophic interactions in the sea: an ecological role for climate relevant volatiles? J. Phycol., 38: 630-638

Steinke, M., Malin, G., Turner, S. M., Liss, P. S. 2000. Determinations of dimethylsulfoniopropionate (DMSP) lyases activity using headspace analysis of dimethylsulphide (DMS). J. Sea Res., 43: 233-244.

Steinke, M., Wolfe, G. V., Kirst, G. O. 1998. Partial characterization of dimethylsulfoniopropionate (DMSP) lyase isozymes in 6 strains of Emiliania huxleyi. Mar. Ecol. Prog. Ser., 175: 215-225.

Steinke, M., Stefels, J. and Stamhuis, E., 2009. Dimethyl sulfide triggers search behavior in copepods. Limnol. Oceangr., 51(4): 1925-1930.

Strickland, T. R., Parsons, T. R. 1968. A practical handbook of seawater analysis. Fish. Res. Board. Can., 167: 1311.

Strom, S., Wolfe, G., Slajer, A., Lambert S., Clough J. 2003. Chemical defense in the microplankton II: Inhibition of protist feeding by $\beta$-dimethylsulfoniopropionate (DMSP). Limnol. Oceanogr., 48: 230-237.

Sunda, W., Kieber, D. J., Kiene, R. P., Huntsman S. 2002. An antioxidant function for DMSP and DMS in marine algae. Nature, 418: 317-320.

Sunda, W., Kiene, R. P., Hardison, R., Bucciarelli E., Harada H. 2007. The effect of nitrogen limitation on cellular DMSP and DMS release in marine phytoplankton: climate feedback implications. Aquatic Science, 69: 341351.

Van Bergeijk, S., Van der Zee, C., Stal, L. 2003. Uptake and excretion of dimethylsulphoniopropionate is driven by salinity changes in the marine benthic diatom Cylindrotheca closterium. Eur. J. Phycol., 38: 341-349.

Wolfe, G. V., Steinke, M, Kirst, G. O. 1997. Grazing-activated chemical defense in a unicellulare marine alga. Nature, 387: 894-897.

Yoch, D. C., Ansede, J. H. and Rabinowitz, K. S., 1997. Evidence for intracellular and extracellular dimethylsulfoniopropionate (DMSP) lyases and DMSP uptake sites in two species of marine bacteria. Appl. Environ. Microbiol., 63: 3182-3188.

Yost, D. M. and Mitchelmore, C. L., 2009. Dimethylsulfoniopropionate (DMSP) lyase activity in different strains of the symbiotic alga Symbiodinium microadriaticum. Marine Ecology Progress Series, 386: 61-70. 